\title{
Dakwah Muslim Progresif dalam Menyikapi Kesetaraan Gender
}

\author{
Ghulam Falach; afha71@gmail.com; Sekolah Tinggi Teknologi Kedirgantaraan \\ Yogyakarta \\ Ridhatullah Assya'bani; rassyabani@gmail.com; Sekolah Tinggi Ilmu Alquran \\ (STIQ) Amuntai
}

\begin{abstract}
Women has long been in a relatively less beneficial position in society compared to their male couterparts. In the Muslim world, this situation has also long been a source of serious discussions among ulamas (experts), especially since Islam is founded upon the spirit of equality and anti-oppression. This paper, thus, deals with ideas from the camp of Progressive Muslims regarding gender equality, especially on the implementation of Islamic Da'wa (proselytizing) to promote gender equality according the perspective of Progressive Muslim. Utilizing literary approach, this paper argues that the implementation of the Da'wa of Progressive Muslims stresses on several aspects such as the importance of critical thinking, being no too textual, being moderate, not being apologetic, and being open about gender issues.
\end{abstract}

Keywords: Da’wa, gender equality, progressive Muslims, and Omid Safi.

\begin{abstract}
Abstrak
Perempuan telah lama berada dalam posisi yang kurang menguntungkan di tengah masyarakat dibandingkan dengan laki-laki. Di dunia Islam, kondisi ini telah lama menjadi bahan perbincangan serius di kalangan para ahli, terutama karena Islam dibangun di atas semangat kesetaraan dan anti opresi. Paper ini, oleh sebab itu, berkaitan dengan gagasan kalangan Muslim Progresif berkenaan dengan kesetaraan gender, terutama dengan pelaksanaan Dakwah Islam untuk mempromosikan kesetaraan gender dalam perspektif Muslim Progresif. Menggunakan pendekatan kepustakaan, hasil analisis dalam artikel ini menunjukkan bahwa Dakwah Muslim Progresif menekankan pada sejumlah aspek seperti; pentingnya bersifat kritis, tidak tekstualis, moderat, tidak apologetis, serta edukatif dan terbuka atas isu-isu gender.
\end{abstract}

Kata Kunci: Dakwah, kesetaraan gender, Muslim progresif dan Omid Safi. 


\section{A. Pendahuluan}

Seiring berjalannya waktu, berganti juga keadaan yang disertai berbagai macam perubahan serta diiringi juga dengan berbagai masalah kehidupan melalui perkembangan yang terjadi di seluruh lini kehidupan. Hal ini secara tidak langsung telah mempengaruhi entitas Islam yang dihadapkan pada berbagai macam akan tantangan perubahan. Slogan Islam yang berbunyi "sholih likulli zaman wal makan" seakan menuntut pertanggungjawaban agar dapat digunakan untuk menyelesaikan problem yang terjadi di tengah masyarakat.

Salah satu tantangan perubahan tersebut datang dari teknologi yang merupakan buah ilmu pengetahuan sebagai jawaban akan tuntutan peradaban modern. Pada awal kehadirannya, teknologi modern dirasa mampu menjadi solusi berkehidupan, namun pada kenyataannya eksistensi teknologi tersebut belum juga dapat menuntaskan berbagai macam permasalahan mendasar manusia. Dikatakan demikian karena peradaban modern yang memprakarsai lahirnya konsep kapitalisme, individualisme, imperialisme ekonomi, dan budaya hedonisme justru menggiring manusia pada bom waktu yang dapat mengancam eksistensi kemanusiaan itu sendiri.

Keterbelakangan kehidupan sosial akibat perbedaan ekonomi, merebaknya kemiskinan, banyaknya pergeseran norma sosial, dan pelanggaran akan prinsip keadilan, hingga munculnya banyak konflik horizontal antar manusia dalam bermasyarakat merupakan backdrop yang layak dinisbatkan pada pemandangan umum abad modern. Bila kenyataan yang terjadi demikian, maka tidak berlebihan jika diutarakan asumsi bahwa nalar peradaban modern tidak seutuhnya sukses dalam berinovasi di ruang kesejahteraan hidup manusia secara umum. ${ }^{1}$

Di tengah dinamika kehidupan bermasyarakat yang semakin semarak, sejumlah paradigma baru pun terus banyak berkembang, salah satunya dalam hal yang berhubungan dengan gender dan isu-isunya. Dikatakan demikian, sebab

${ }^{1}$ Khaled Abou el-Fadl, Selamatkan Islam dari Muslim Puritan, ed. oleh M. Musthafa, trans. oleh Helmi Mustofa, 1 ed. (Jakarta: PT. Serambi Ilmu Semesta, 2006), 21. 
jikalau dibenturkan dengan pemikiran Islam maka berbagai macam perspektif akan terlahirkan. Konsekuensinya, kesakralan penuh yang dimiliki tiap agama cenderung menjadi tidak lagi spesial di mata para penganutnya. Pengharapan awal akan motivasi keadilan dan kesetaraan bersama demi mewujudkan salah satu misi penting agama ternyata berbalik arah dengan penodaan melalui asas kepentingan sesaat yang bersifat pribadi. Pada hakikatnya, seluruh agama, termasuk, Islam tidak memiliki ajaran yang bersifat kontradiktif dengan misi utama yang diusung, akan tetapi umatnya sendiri yang sering kali bersikap ceroboh dan bertingkah kontradiktif dengan mengatasnamakan agama. ${ }^{2}$

Merespons akan hal tersebut, sejumlah cendekiawan muslim yang beridentitaskan Progressive Moslem berusaha untuk menghadirkan perspektif baru melalui paduan pemikiran Islam dengan isu-isu populer Islam yang kontemporer. Omid $\mathrm{Safi}^{3}$ yang merupakan pencetus pergerakan tersebut bersama cendekiawan muslim lainya bersama-sama menuangkan pemikiran mereka demi terwujudnya keseimbangan dan kesetaraan terkhusus dalam ruang gender. Dimaksudkan demikian karena isu akan hak-hak perempuan telah bermunculan di beberapa bagian dunia, sementara di daerah bagian lain tampak tidak terlalu dimunculkan dan cenderung diacuhkan. Dalam perkembangannya, gerakan Muslim Progresif mengakui pentingnya berjuang untuk kesetaraan gender sebagai salah satu agenda penting yang mereka usung. ${ }^{4}$

Beberapa langkah yang mereka gunakan untuk mewujudkan agendaagendanya adalah; Berpegang teguh kepada Alquran dan Hadits, juga mengkorelasikan dengan isu-isu kontemporer yang dapat menghadirkan alternatif baru, perlawanan terhadap tendensi sekuler yang selalu digaungkan dengan

2 Omid Safi, ed., Progressive Muslims: On Justice, Gender and Pluralism, Reprinted (Oxford: Oneworld, 2010), 22.

${ }^{3}$ Omid Safi adalah pemikir Muslim berkebangsaan Amerika Serikat berdarah Iran. Karir akademisnya dimulai dari North Carolina University sebagai alamamater utamanya. Di sini ia meraih posisi asisten professor, sebelum akhirnya pada tahun 2010 dianugerahi gelar sebagai guru besar. Omid Safi meraih penghargaan sebagai pengajar dan dosen tamu favorit dari beberapa perguruan tinggi lain di Amerika, seperti Colgate University, Duke University, dan Harvard University. Lihat, Omid Safi, Progressive Muslims, x.

${ }^{4}$ Omid Safi, Progressive Muslims. 
menampilkan kesantunan dan akhlak spiritual Islami, dan selalu melibatkan diri dengan tradisi intelektual dan memberikan kesegaran bagi semangat spiritualitas Islam. $^{5}$

Sebelum membahas lebih lanjut sepak terjang pemikiran Moslem Progressive dalam menindak lanjuti kesetaraan gender, perlu kiranya terlebih dahulu kita memahami perihal pergerakan ini dan selayang pandang latar belakang gender sebagai pokok permasalahan. Di lain sisi sebenarnya penarikan benang merah atas konsep yang dihadirkan oleh pergerakan ini tidak serta merta dipahami sebagai konsep baku dan sudah final, namun malah lebih diharuskan untuk terus mengkaji dan mendiskusikannya agar perkembangannya berdampak terhadap kelanjutan ilmu pengetahuan khususnya dalam ranah keislaman. Maka berpijak pada hal tersebut diharapkan ke depannya sedikit dari apa yang sudah dihasilkan dapat menghadirkan pemahaman atas apa yang telah dicurahkan oleh para cendekiawan muslim dalam karya-karya serta konsep pemikirannya.

\section{B. Genealogi Kesetaraan Gender}

Etimologi kata gender pada awalnya muncul dari basic kata berbahasa Inggris yang bermakna jenis kelamin. Dalam Bahasa Indonesia, kata gender memiliki arti kelamin dan mengarah pada seks seseorang. ${ }^{6}$ Meminjam istilah yang dijelaskan oleh Stoller, Alifiulahtin, dipaparkan bahwa gender merupakan bentuk perbedaan dalam segi biologis dan bukan semata kodrat Tuhan YME. Dijelaskan oleh Stoller bahwa gender tersebut merupakan konstruksi kehidupan sosial atau atribut yang dipakai manusia dan merupakan hasil dari kebudayaan manusia itu sendiri. Dimaksudkan perbedaan biologis karena adanya unsur jenis kelamin yang berbeda dan merupakan kodrat Tuhan YME, sedangkan gender tidak dimaksudkan demikian. Gender tersebut tidak lain adalah perbedaan perilaku terkait dengan tugas

${ }^{5}$ M. Toha, "Paradigma Baru Fiqih Perempuan" (Makalah, Surabaya, Program Pascasarjana IAIN Sunan Ampel, 2015).

${ }^{6}$ Meity Taqdir Qodratillah dkk., Tesaurus Bahasa Indonesia Pusat Bahasa (Jakarta: Pusat Bahasa Departemen Pendidikan Nasional, 2008), 168. 
serta fungsi antara laki-laki dan perempuan berdasarkan hasil konstruksi kultural berkehidupan sosial dan berbudaya melalui perjalanan dan proses yang panjang. ${ }^{7}$

Terlepas dari hal itu, diskursus mengenai gender tampak memiliki asumsi yang condong pada perbedaan jenis kelamin di ranah masyarakat sosial. Merujuk pada Encyclopedia of Women's Studies, gender dinilai merupakan bentuk akulturasi konsep perbedaan posisi di ruang konstruksi sosial mengenai karakter, perilaku, sikap, dan peran antara laki-laki dan perempuan secara emosional. Sebagaimana diketahui secara umum perihal anggapan posisi wanita memperoleh peluang yang minimal untuk berpartisipasi secara langsung di bidang pencarian nafkah perekonomian daripada laki-laki. Dalam hal ini, perempuan mendapatkan akses untuk berkecimpung dalam strata pendidikan dasar maupun tinggi yang cenderung minimal. Demikian juga halnya di bidang politik dan sejumlah bidang kehidupan sosial lainnya. Keseluruhan hal ini secara tidak langsung telah menjadi fondasi dasar akan bergaungnya suara kesetaraan gender di kancah global. ${ }^{8}$

Secara umum, dinamika gender terlihat pelik dan dinilai perlu untuk terus dieksplorasi. Pada dasarnya gender merupakan salah satu bagian dari keadilan sosial yang berada pada konstruksi pemikiran manusia. Oleh sebab itu, diskursus akan hal tersebut termasuk dalam kategori dinamis yang senantiasa berubah seiring perkembangan pemikiran dalam tatanan kehidupan manusia.

Secara global, dapat dikatakan bahwa tidak ada negara yang sepenuhnya mencapai kesetaraan gender. Negara-negara Skandinavia seperti Islandia, Norwegia, Finlandia, dan Swedia memimpin dunia dalam kemajuan mereka menuju penutupan kesenjangan gender. Pada negara-negara tersebut tampak distribusi yang relatif merata dari pendapatan, sumber daya, dan peluang untuk pria dan wanita dalam berekspresi di ranah publik. Kesenjangan gender terbesar diidentifikasi jelas terlihat di Timur Tengah, Afrika, dan Asia Selatan. Namun,

${ }^{7}$ Alifiulahtin Utaminingsih, Gender dan wanita karir (Malang: UB Press, 2017), 3.

${ }^{8}$ Helen Tierney, ed., Women's studies encyclopedia (New York: Greenwood Press, 1989). 
sejumlah negara di wilayah tersebut seperti Lesotho, Afrika Selatan, dan Sri Lanka mengungguli Amerika Serikat dalam hal kesetaraan gender. ${ }^{9}$

\section{Islam Progresif}

Wacana tentang progresivitas Islam dirasa marak menjadi bahan perbincangan di berbagai tempat sebagai respon atas krisis dan kebekuan yang menimpa pemikiran umat Islam. Kajian-kajian tersebut dipicu oleh beberapa faktor seperti untuk merespons secara positif perspektif negatif masyarakat dunia yang senantiasa menilai Islam sebagai tidak cepat dalam menyikapi perkembangan zaman, tumbuhnya kesadaran mengenai strategi untuk menepis anggapan ekstremis yang selalu dilayangkan kepada Islam adalah melalui pengoptimalan fungsi indikator-indikator berkemajuan (progressive) umat muslim dan menghubungkannya dengan masyarakat lain. Selain itu, kehadiran muslim progresif bukan sekedar mendasari pemikirannya melalui Alquran dan as-Sunnah yang dibawa dan diajarkan oleh Nabi Muhammad SAW saja, namun juga mengkorelasikannya dengan realitas kekinian yang berkembang kehidupan masyarakat. ${ }^{10}$

Sebelum masuk kepada epistemologi Progressive hendaknya kita perlu mengetahui bahwa hadirnya konsep baru dalam dunia Islam ini dilatar belakangi oleh kritik kaum epistemis terhadap golongan-golongan Islam berada pada kategori rejeksionisme dan tradisionalisme konservatif. Golongan Islam yang berkategori tradisionalisme konservatif dikenal secara terang-terangan mengedepankan asumsi kejayaan Islam masa lampau sebagai era gemilang yang tak dapat dibantah dan digugat. Spirit pijakan pemikiran tradisi yang tidak diiringi korelasi modernitas dengan mengusung slogan Sholakhiyah likulli zaman wa makan sering kali menjerumuskan mereka pada pereduksian makna karena kuatnya pemikiran golongan tersebut pada penolakan terhadap modernitas dan lebih condong

9 Martinus Sardi, "Menuju Masyarakat Berwawasan HAM: Berbasis Lokal, Bervisi Internasional," dalam Islam dan HAM: Diskursus dan Pengalaman Indonesia (Yogyakarta: Kuakaba Dipantara, 2014), 5-6.

${ }^{10}$ Omid Safi, Progressive Muslims, 4. 
mengekor pada kejayaan masa lalu. Bagi mereka bukan Islam yang mengikuti zaman, akan tetapi zamanlah yang harus mengikuti Islam. Oleh karena itu tak ayal bila golongan tersebut sering terbawa arus bersikap ekstremis dengan mengatasnamakan jihad Islam. Sedangkan golongan Islam berkategori rejeksionisme dengan jelas menolak berbagai macam bentuk modernitas yang dianggap telah menghilangkan kekuasaan Tuhan dan lebih menghadirkan kekuasaan manusia. Bagi golongan tersebut, orang-orang yang berpikir tentang modernisasi Islam merupakan kesalahan dan beranggapan bahwa usaha tersebut akan berujung kegagalan. Anggapan kuat mereka bahwa upaya modernisasi tidak diperlukan lagi sebab Islam sudah begitu sempurna dan berlaku bagi setiap zaman. $^{11}$

Berdasarkan dua kategori golongan tersebut dapat dilihat bahwa historisitas tidak lagi ada harganya. Bagi mereka hakikat realitas hanya milik masa lampau, begitu juga sebaliknya. Menurut Muslim Progresif perspektif mereka tidak begitu kuat untuk menghadirkan bentuk keeleganan Islam. Maksud elegan dalam hal ini adalah Islam yang pandai menyesuaikan dan pantas diperbincangkan dengan modernitas, namun bersamaan dengan hal tersebut tidak tereduksi keotentikannya dan tetap terjaga identitas serta tradisinya.

Munculnya Islam Progresif tidak lain untuk mempertegas eksistensi Islam di mana istilah tersebut merujuk pada semacam sintesis antara Islam fundamental dengan Islam liberal. Selain itu, istilah tersebut juga menjelaskan pada kedua belah pihak bahwa golongan mereka dinilai tidak menjunjung tinggi historisitas Islam. Misi Islam sejak awal adalah liberasi atau pembebasan dari berbagai penindasan, tirani, dan ketidakadilan. Perhatian dan penekanan akan hal tersebut diharuskan sehingga tidak terjadi hegemoni pembenaran sepihak ataupun penyesatan. Jika demikian keadaannya, maka perubahan memang menjadi kebutuhan sebuah agama bila tidak ingin terperosok dalam kubangan anakronisme. Namun, dilain sisi aspek kontinuitas (continuity) juga mutlak diperhatikan dan dibutuhkan demi memagari

11 Budhy Munawar Rachman, Argumen Islam untuk liberalisme (Jakarta: Gramedia Widiasarana Indonesia, 2010), 130. 
agama dari beragam serangan golongan luar Islam, baik kaum rasionalis maupun kaum sekuler. ${ }^{12}$

Dalam konteks pembahasan secara epistemologi, istilah muslim progresif dijelaskan oleh para pakar secara cukup beragam. Cendekiawan muslim Abdullah Saeed mendefinisikan muslim progresif sebagai bagian dari sekian ragam kelompok pemikiran Islam kontemporer yang memiliki upaya dalam menghadirkan kontekstualisasi untuk menjawab kebutuhan kaum muslim modern yang mempunyai maksud dan tujuan untuk melestarikan semangat akan keberagaman tradisi dan pemikiran Islam. ${ }^{13}$ Definisi lain diungkapkan oleh Syed Hussein Alatas yang memaparkan perspektifnya mengenai muslim progresif, yaitu gagasan bahwa Islam tidak menyiratkan reduksi maupun abstraksi akan bentuk totalitas Islam itu sendiri sebab pada hakikatnya Islam sejak awal kehadirannya telah mengindikasikan corak yang progresif.

Omid Safi kemudian menjelaskan rumusan makna progress (maju) sebagai istilah dasar akan suatu hal yang dapat dikatakan maju bilamana bercirikan dapat menghadirkan tagyir (revolusi) dan tajdid (pembaharuan) ke sudut yang dirasa lebih berfungsi, lebih berprospek, dan lebih ada manfaatnya untuk kepentingan umat manusia secara menyeluruh dalam berkehidupan. Inti gagasan muslim progresif adalah berpijak pada nilai-nilai di dalam Alquran yang dapat direvitalisasi dan memiliki makna penting bagi peradaban Islam di abad ini. Oleh karena itu dalam perumusan makna muslim progresif hendaknya berdasarkan pada keadilan universal tanpa adanya monopoli kemakmuran dan juga kebaikan atau keindahan (al-ihsan). Meski dikenal sebagai perumus konsep tersebut, Omid Safi tidak serta merta membenarkan hal tersebut. Safi tidak ingin muslim progresif identik dengan

\footnotetext{
${ }^{12}$ Advokasi liberal Islam secara umum menunjukkan identifikasi yang tidak kritis terhadap dan nyaris mengabdi kepada modernitas, serta sering (tetapi tidak selalu) tidak mengindahkan diskusi tentang kolonialisme dan imperialism. Lihat, Omid Safi, Progressive Muslims, 3.

13 Tholhatul Choir, Ahwan Fanani, dan Abdul Basith Junaidi, Islam dalam berbagai pembacaan kontemporer, 1 ed. (Yogyakarta: Pustaka Pelajar, 2009), 526.
} 
kritikan semata, namun juga membuka pemikiran lain untuk bersama mengkaji progresifitas tersebut. ${ }^{14}$

\section{Dakwah Berparadigma Kesetaraan Gender Muslim Progresif}

Dalam praktiknya muslim progresif terindikasi menggunakan tiga karakteristik dakwah yang khas untuk melancarkan gagasannya. Karakteristik pertama tampak pada dakwah yang didasari dengan anti pemungutan secara tekstualis terhadap pemaknaan literasi keislaman di mana hal ini merupakan warisan tradisi Islam klasik secara historis. Karakteristik ini memberikan ciri khas dakwah Muslim Progresif yang berupaya untuk menghadirkan keyakinan bagi umat Islam akan tahapan awal dalam melancarkan proyeksi modernisasi Islam. Hal ini dapat ditempuh melalui rancangan epistemologi Islam yang dikonstruksi secara radikal berlandaskan Alquran dan Hadits sebagai pilar utama untuk pengembangan bidang keilmuan dalam Islam.

Karakteristik kedua adalah dakwah melalui sikap rasional dan selektif atas berbagai wacana dan paradigma kontemporer yang mayoritas telah dipopulerkan oleh Barat. Harapan dari karakteristik ini adalah agar umat Islam mampu memainkan peran ganda di mana pada satu sisi mereka memosisikan diri secara permisif, bahkan cenderung adaptif terhadap berbagai wacana kontemporer, namun di lain sisi tidak menafikan sikap berpikir kritis terhadap beberapa efek problematik hasil proyeksi modernitas Barat. Sedangkan karakteristik ketiga adalah perihal posisi diri umat Islam di luar apologetis. Dalam dakwah ini diharapkan muslim progresif mampu menghadirkan harapan untuk menghilangkan dilema ketidakpastian umat Islam, yaitu antara terikat dengan tradisi, dan ketanggapan akan kebutuhan dengan modernitas Barat. Pada intinya penanaman akan keseimbangan karakteristik tersebut menjadi acuan utama muslim progresif dalam

14 Syukron Affani, Tafsir Al-Qur'an dalam Sejarah Perkembangannya, 1 ed. (Jakarta: Kencana, 2019), 180. 
melancarkan dakwah pergerakannya, hal ini dikarenakan antar karakteristik tersebut saling berkaitan satu dengan lainnya. ${ }^{15}$

Menapaki ranah gender, muslim progresif mengawali dakwah dengan pandangan bahwa kaum muslimin tidak akan dapat merealisasikan kesetaraan gender tanpa menghadirkan jaminan keadilan bagi seluruh kaum wanita, terkhusus Muslimah. Kesetaraan gender dalam hal ini berkedudukan sebagai salah satu tolak ukur bagi problematika yang lebih luas mengenai ranah pluralisme dan keadilan sosial. Sebelum melangkah lebih jauh, yang perlu dipahami bahwasanya paradigma gender tidak sekedar menyinggung ranah perempuan saja akan tetapi ranah lakilaki juga penting untuk ditindak lanjuti. Fokus akan paradigma gender yang dirasa condong pada kedudukan perempuan senantiasa bukan bermaksud untuk pemberian keadilan bagi kaum perempuan atas dasar rasa belas kasihan maupun hadiah saja, namun perlu diingat bahwasanya mereka adalah bagian dari umat manusia dengan hak-hak yang harus diraih. ${ }^{16}$

Dalam hal ini sejumlah kalangan berkeyakinan bahwa Islam merupakan agama yang pertama kali memiliki agenda untuk mengangkat harkat dan martabat perempuan. Yvonne Y. Haddad, salah seorang yang mengamini pendapat tersebut, melalui serangkaian tinjauan sejarah masyarakat Arab secara komprehensif, menyimpulkan bahwa Islam tidak sekedar hadir sebagai seonggok teologi baru bagi masyarakat Arab yang saat itu masih erat dengan keyakinan yang bersifat politeistis, namun juga hadir untuk menggulirkan perubahan radikal pada ranah sosial masyarakat Arab. Salah satu perubahan radikal yang dilakukan Islam adalah menghapus tradisi patriarki yang sudah mendarah daging dalam masyarakat Arab. Ketika itu, pada abad ke VII M di mana sebagian besar peradaban dunia menganggap budaya diskriminasi terhadap perempuan sebagai tradisi yang wajar. ${ }^{17}$

${ }^{15}$ Omid Safi, Progressive Muslims, 3.

${ }^{16}$ Khaled Abou el-Fadl, Selamatkan Islam dari Muslim Puritan, 300.

${ }^{17}$ Mansour Fakih, Membincang Feminisme: Diskursus Gender dalam Perspektif Islam, 1 ed. (Surabaya: Risalah Bukti, 2000), 155. 
Di lain sisi, kehadiran Islam memang dapat dikatakan sebagai bentuk hadiah pada perempuan-perempuan Arab atas sejumlah hak yang sebelumnya tidak pernah mereka dapatkan. Lebih lanjut menurut Yvonne Y. Haddad, setidaknya ada tujuh capaian penting Islam yang berkaitan dengan usaha-usaha pengangkatan harkat dan martabat perempuan.

- Pertama, pada dimensi spiritualitas, di mana perempuan dan laki-laki samasama memiliki hak, akses, dan kesempatan yang sama untuk menyembah dan mendekatkan diri pada Allah SWT. Islam tidak membedakan tingkat spiritualitas berdasar pada jenis kelamin, melainkan berdasar pada ketakwaan masing-masing individu. Perempuan yang beramal saleh mendapat pahala dengan kadar yang sama sebagaimana diterima laki-laki (QS. Al-Hujarat: 13).

- Kedua, dari status kejadian (peristiwa), Islam menerangkan bahwa baik lakilaki maupun perempuan diciptakan oleh Allah dalam derajat yang sama (QS. An-Nisa:1).

- Ketiga, dari segi mendapatkan godaan, Alquran menyebutkan bahwa godaan yang dilancarkan iblis berlaku bagi laki-laki dan perempuan, sebagaimana yang terjadi pada tragedi Adam dan Hawa.

- Keempat, dari segi kemanusiaan, di mana kondisi perempuan Arab prakedatangan Islam bisa dikatakan berada pada titik nadir, di mana perempuan lebih sering diposisikan sebagai "the second class". Bahkan, di beberapa suku Arab kuno, berlaku tradisi penguburan bayi perempuan. Islam datang dengan memberikan seruan yang jelas bahwa tindakan tersebut jauh dari nilai moralitas (QS. An-Nahl: 58).

- Kelima, dari segi kepemilikan dan kepengurusan harta, dijelaskan dalam Islam, perempuan memiliki hak untuk membelanjakan harta pribadinya sebagaimana hak laki-laki (QS. An-Nisa:32).

- Keenam, dari segi warisan, di mana sebelum Islam datang, jangankan memiliki hak waris, perempuan justru menjadi barang warisan ketika suaminya meninggal. Paradigma tersebut secara drastis berhasil diubah Islam dengan memberikan hak waris bagi perempuan (QS. An-Nisa: 7). Ketujuh, dari segi 
kedudukan di muka hukum, dijelaskan dalam Islam, laki-laki dan perempuan memiliki 27 hak dan kedudukan yang sama di hadapan hukum, terutama menyangkut persoalan perceraian, perzinaan dan hubungan suami istri.

Penjelasan dakwah progresif Islam dilanjutkan dengan perspektif pemikir dari Muslim progresif, di mana dalam persoalan gender tersebut gagasan Khaled Abou El Fadl tampaknya sejalan dengan Yvonne Y. Haddad yang menilai akar persoalannya bukan pada teks keagamaan, melainkan pada kegagalan umat Islam dalam menangkap semangat (spirit-geist) yang dikandung teks tersebut. Sejalan dengan Yvonne Haddad, Khaled Abou El Fadl berpendapat bahwa dalam konteks kekinian, umat Islam seharusnya tidak hanya memaknai teks keislaman melalui penafsiran luar (harfiahnya) semata atau secara tekstualis. Realitas (dalam hal ini tantangan) kontemporer menuntut umat Islam untuk mampu mengungkap makna terdalam dari teks keislaman. Apa yang diberikan Islam pada perempuan Arab di abad ke VII M misalnya (tentang hak waris dan hak mendapatkan mahar), bukanlah regulasi hukum yang statis, melainkan akan selalu dinamis dan menyesuaikan kecenderungan zaman. ${ }^{18}$

Omid Safi ikut menuturkan perihal problem gender dalam Islam. Baginya, kesetaraan gender tidak selalu dihubungkan dengan penindasan perempuan saja, tetapi juga berhubungan dengan laki-laki juga perlu untuk ditindaklanjuti. Muslim progresif mengawali permasalahan gender dengan sikap yang sederhana namun radikal. Bagi mereka, kaum Muslimah secara keseluruhan tidak dapat mencapai keadilan kecuali keadilan tersebut telah terjamin bagi mereka. Secara sederhana hal ini dapat dikatakan sebagai tidak ada interpretasi progresif tentang Islam tanpa terbentuknya keadilan gender. Pengkajian isu-isu gender dalam keilmuan Islam tidak hanya berkutar pada penindasan tetapi juga penindasan pada kaum laki-laki yang berpartisipasi di dalamnya juga menjadi urgen. Muslim progresif memperjelas dengan perspektif mereka, bahwa melalui isu gender tidak bermaksud hanya berfokus pada hijab (penutup kepala perempuan Muslimah), seperti hijab tidak

${ }^{18}$ Yvonne Yazbeck Haddad dan John L. Esposito, ed., Islam, Gender, \& Social Change (New York: Oxford Univ. Press, 1998), 3-5. 
dipandang menjadi penanda sebagai identitas seorang Muslimah, namun muslim progresif juga menolak segala bentuk kekerasan pada perempuan baik yang bersifat verbal maupun non-verbal melalui regulasi religiositas dan harkat martabat perempuan seperti yang telah di ajarkan pada masa awal Islam. ${ }^{19}$

Menengok kembali ke abad yang jauh dari masa sekarang, di mana Rasulullah SAW telah menghadirkan ruh perjuangan perihal gender. Munculnya hal ini tidak lain dipicu dengan maraknya perbudakan dan penindasan terhadap kaum wanita. Meski tidak berjalan mulus pada awal perjuangannya, namun Rasulullah SAW bersama para sahabat selalu ingin menunjukkan kegigihan dan semangat Islam sebagai agama rahmatan lil 'alamin. ${ }^{20}$ Sosok Aisyah r.a yang telah didelegasikan Rasulullah SAW untuk berjuang melalui dakwah dengan memberikan ajaran dan ujaran berbasis keislaman di mana hal ini sama persis seperti yang dilakukan oleh para sahabat laki-laki lainya merupakan salah satu bentuk kesetaraan gender yang dirasa berhasil dipentaskan pada masa itu. Bersandarkan akan keadaan tersebut, Islam jelas telah menentang segala bentuk diskriminasi terhadap perempuan, bahkan pemarjinalan dan pengasingan perempuan yang memiliki inovasi "positif" bukanlah hal yang diharapkan oleh Islam. Hal ini karena pada hakikatnya setiap individu manusia baik laki-laki maupun perempuan terlahir dengan hak dan kewajiban yang sama terhadap Allah SWT sebagai khalifatullah fi al ardhi. ${ }^{21}$

Meski pada masa Islam awal dengan hadirnya Rasulullah SAW dan para sahabat telah menghapuskan segala bentuk diskriminasi dan perbudakan atas perempuan, akan tetapi bila terjadi di tempat lain maka seharusnya sudah ditinggalkan seiring berkesudahannya sistem imperialisme dan kolonialisme. Perbedaan antropologis dan budaya tidak harus mengaburkan kesetaraan gender yang memang menjadi hak dasar keseluruhan umat manusia. ${ }^{22}$ Paradigma baru yang

\footnotetext{
${ }^{19}$ Omid Safi, Progressive Muslims, 10-11.

${ }^{20}$ Cliver Name, Muslimah Pembawa Perubahan, 1 ed. (Surabaya: H.M. Production, 2020), 10.

${ }^{21}$ Jamhari dan Ismatu Ropi, Citra Perempuan dalam Islam, 1 ed. (Jakarta: PT. Gramedia Pustaka Utama, 2003), 7.

${ }^{22}$ Nurrochman, "Pemikiran Islam Progresif Khaled Abou el-Fadl” (Tesis, Yogyakarta, UIN Sunan Kalijaga, 2011).
} 
hadir adalah munculnya Feminisme dan maskulinitas sebagai bagian dari perbedaan antropologis dan budaya. Problema akan paradigma tersebut muncul dikarenakan setiap daerah memiliki sistem dan konsep yang berbeda akan batasan hal tersebut. Selain itu, problem hadir karena banyaknya masyarakat yang belum dapat membedakan antara pemahaman kedua hal tersebut dengan gender. Bila dikaji tentu hal tersebut memiliki perbedaan yang signifikan, di mana feminisme lebih cenderung kepada dialektika seputar perempuan dengan berbagai fenomenanya dan maskulinitas condong pada seputar laki-laki dengan berbagai problemnya. Hadirnya kajian atas feminisme dan maskulinitas muncul dari asas terciptanya lakilaki dan perempuan yang jelas memiliki perbedaan secara jenis kelamin. Namun hal ini akan berbeda bila memasuki ranah gender, di mana konotasi pemahamannya harus berpindah secara rasio, hasrat, kondisi psikologis, intelegensi, tanpa menyentuh ranah perbedaan antara laki-laki dan perempuan. Paradigma akan pergeseran pemahaman antara feminisme, maskulinitas, serta gender merupakan salah satu fokus muslim progresif dalam mengupayakan segala bentuk pembelajaran dan pemahaman kepada seluruh masyarakat agar terhindar dari kesalahpahaman. $^{23}$

Melalui upaya pembelajaran dan penanaman pemahaman dalam dakwah muslim progresif untuk menyikapi paradigma gender ini, setidaknya tawaran sikap yang disuguhkan oleh Omid Safi memberikan arahan supaya tidak terjadi kesalahpahaman dan kekeliruan dalam melakukan pembaharuan. Adapun tawaran tersebut mencakup di antaranya; pertama, dalam membaca situasi saat ini, terutama masalah gender hendaknya seorang muslim progresif harus menelusuri khazanah Islam klasik terlebih dahulu sebelum melakukan interpretasi terhadap kesetaraan gender, tanpa pembacaan ulang terhadap khazanah klasik Islam seorang muslim progresif hanya sekadar bersikap apologetis dengan ujaran keadilan, kesetaraan gender, pluralisme dan lain sebagainya. Sikap ini merupakan bagian penghormatan terhadap tradisi agama Islam (ulum ad-ddin) yang telah mengakar ribuan tahun. Sikap ini akan memberikan pemahaman terhadap dakwah gender di era

\footnotetext{
${ }^{23}$ M. Toha, "Paradigma Baru Fiqih Perempuan."
} 
kontemporer ini. Sebagai seorang muslim yang progresif tidak mesti mengabaikan peninggalan klasik Islam, bahkan mereka menolak terhadap sekularisasi yang hendak menyerabut Islam dari akar tradisinya. Pada posisi inilah muslim progresif harus mampu mengembangkan suatu pemahaman agama dalam menyikapi isu-isu gender saat ini.

Kedua, menghindari sikap apologetis. Semakin hari semakin bertambah masalah yang dihadapi manusia, tidak terkecuali juga umat Islam yang memerlukan upaya yang tidak sederhana untuk menjawabnya. Terlebih perkembangan sains dan teknologi yang begitu masif menuntut masyarakat muslim untuk bersikap kritis agar tidak terjebak pada pemikiran stagnan. Tidak jarang pemikiran stagnasi yang merujuk langsung pada nilai absolut Islam menjadi pilihan sebagian ulama dalam menjawab persoalan kontemporer tanpa mempertimbangkan aspek rasionalitas, kontekstualitas, kondisi sosio-kultural ketika ayat turun dan makna universal ayat. Situasi inilah yang kemudian melahirkan sikap pragmatis dan apologetis yang berakibat tidak mampu menemukan solusi terhadap masalah-masalah kontemporer.

Bagi Omid Safi, mereka yang mengacu pada otoritas Islam tanpa mempertimbangkan aspek lain, layaknya mereka ber-Islam dengan kemalasan dalam menginterpretasi Alquran. Ketiga, kesamaan persepsi dan komitmen untuk mengerjakan program yang telah ditetapkan secara bersama dalam membangun Islam yang rahmatan lil 'alamin. Bagi Omid Safi, sesempurna apa pun program yang dibuat namun tidak diimbangi dengan Tindakan maka program tersebut tidak berarti apa-apa. Bagi muslim progresif, tindakan yang dimaksud di sini adalah memaksimalkan program yang telah ditentukan, terutama pada ranah sosial, terutama membantu kaum-kaum tertindas, membela hak perempuan, hak asasi manusia, menyeru pada perdamaian, yang semua ini pada dasarnya menjadi tradisi Islam dan tidak pernah membatasi ras, suku bangsa, etnik dan sebagainya. Inilah yang harus dilakukan oleh muslim progresif dalam menyikapi berbagai masalah yang dihadapi. 
Keempat, mengutamakan aspek humanisme dan etika. Aspek humanisme inilah yang menjadi roh perdamaian di dunia, sedangkan etika diposisikan sebagai kode etik relasi antar sesama manusia. Seseorang yang tidak memiliki spirit humanisme dan etika akan mudah dalam menjustifikasi seseorang salah, sesat, kafir dan sejenisnya. Paradigma gender merupakan salah satu bagian sistem pembaharuan dalam Islam pada aspek humanisme, di mana melalui mengangkat harkat martabat perempuan dan meletakkan kode etik secara universal. Kelima, open minded (keterbukaan) terhadap segala informasi dalam pengembangan ilmu pengetahuan. Sikap ini setidaknya memberikan penyegaran terhadap solusi terhadap masalah yang sedang dihadapi. Muslim progresif tidak diperkenankan hanya mengambil sumber hanya dari Alquran dan Hadis saja, tetapi juga harus memiliki kekayaan khazanah intelektual Islam dari berbagai sumber yang representatif.

Oleh sebab itu, untuk menyikapi paradigma gender dalam Islam harus melalui tahapan atau proses yang tidak sederhana, perlu suatu tindakan yang konsisten dan simultan seperti, melalui ranah pendidikan untuk memuat kurikulum dan bahan ajar yang di dalamnya menyelipkan paradigma kesetaraan gender serta berpikiran moderat. Karena tidak hanya lelaki yang mampu memainkan peran sosial yang baik, tetapi juga perempuan mampu melakukan layaknya lelaki lakukan dalam ranah sosial. Inilah mengapa dakwah muslim progresif harus terus didengungkan demi terciptanya keseimbangan dan keadilan.

\section{E. Kesimpulan}

Berdasarkan penjelasan di atas dapat disimpulkan bahwa karakteristik dalam dakwah muslim progresif setidaknya memiliki tiga hal; tidak menggunakan pemahaman tekstual dalam memahami Alquran atau Hadis; mengedepankan rasionalitas dan mampu menyaring berbagai wacana popular terhadap paradigma baru; dan memberikan kepastian terhadap umat Islam. Ada beberapa sikap dakwah muslim progresif dalam menyikapi paradigma gender, yakni; kritis terhadap problem gender; tidak bersikap apologetis, moderat, memberikan pemahaman dan 
edukatif mengenai gender, memosisikan perempuan sama dengan laki-laki dalam ranah sosial, politik, dan ekonomi dalam keseharian dan membuka wawasan terhadap permasalahan gender.

132|Lentera, Vol. IV, No.2, Desember 2020 


\section{DAFTAR PUSTAKA}

Alifiulahtin Utaminingsih. Gender dan wanita karir. Malang: UB Press, 2017.

Budhy Munawar Rachman. Argumen Islam untuk liberalisme. Jakarta: Gramedia Widiasarana Indonesia, 2010.

Cliver Name. Muslimah Pembawa Perubahan. 1 ed. Surabaya: H.M. Production, 2020.

Helen Tierney, ed. Women's studies encyclopedia. New York: Greenwood Press, 1989.

Jamhari dan Ismatu Ropi. Citra Perempuan dalam Islam. 1 ed. Jakarta: PT. Gramedia Pustaka Utama, 2003.

Khaled Abou el-Fadl. Selamatkan Islam dari Muslim Puritan. Disunting oleh M.

Musthafa. Diterjemahkan oleh Helmi Mustofa. 1 ed. Jakarta: PT. Serambi Ilmu Semesta, 2006.

M. Toha. "Paradigma Baru Fiqih Perempuan.” Makalah, Program Pascasarjana IAIN Sunan Ampel, 2015.

Mansour Fakih. Membincang Feminisme: Diskursus Gender dalam Perspektif Islam. 1 ed. Surabaya: Risalah Bukti, 2000.

Martinus Sardi. "Menuju Masyarakat Berwawasan HAM: Berbasis Lokal, Bervisi Internasional." Dalam Islam dan HAM: Diskursus dan Pengalaman Indonesia, 31-54. Yogyakarta: Kuakaba Dipantara, 2014.

Meity Taqdir Qodratillah, Adi Budiwiyanto, Dewi Puspita, Dora Amalia, dan Teguh Santoso. Tesaurus Bahasa Indonesia Pusat Bahasa. Jakarta: Pusat Bahasa Departemen Pendidikan Nasional, 2008.

Nurrochman. "Pemikiran Islam Progresif Khaled Abou el-Fadl." Tesis, UIN Sunan Kalijaga, 2011.

Omid Safi, ed. Progressive Muslims: On Justice, Gender and Pluralism.

Reprinted. Oxford: Oneworld, 2010.

Syukron Affani. Tafsir Al-Qur'an dalam Sejarah Perkembangannya. 1 ed. Jakarta: Kencana, 2019. 
Tholhatul Choir, Ahwan Fanani, dan Abdul Basith Junaidi. Islam dalam berbagai pembacaan kontemporer. 1 ed. Yogyakarta: Pustaka Pelajar, 2009.

Yvonne Yazbeck Haddad dan John L. Esposito, ed. Islam, Gender, \& Social Change. New York: Oxford Univ. Press, 1998. 